\title{
The Prerequisite of \\ the Success in Plant Tissue Culture: \\ High Frequency Shoot Regeneration
}

\author{
Mustafa Yildiz \\ Additional information is available at the end of the chapter
}

http://dx.doi.org/10.5772/51097

\section{Introduction}

Plant tissue culture is a term containing techniques used to propagate plants vegetatively by using small parts of living tissues (explants) on artificial growth mediums under sterile conditions. Explants regenerate shoots and roots, and consequently whole fertile plants under certain cultural conditions. Micropropagation is the production of whole plants through tissue culture from small parts such as shoot and root tips, leaf tissues, anthers, nodes, meristems and embryos. Micropropagation is the vegetative (asexual) propagation of plants under in vitro conditions and is widely used for commercial purposes worldwide [1-3].

Plant tissue culture techniques have certain advantages over traditional ones of propagation.

These are:

- Thousands of mature plants can be produced in a short time that allows fast propagation of new cultivars,

- Endangered species can be cloned safely,

- Large quantities of genetically identical plants can be produced,

- Plant production is possible in the absence of seeds,

- The production of plants having desirable traits such as good flowers, fruits and odor is possible,

- Whole plants can be regenerated from genetically modified plant cells,

- Disease-, pest- and pathogen-free plants in sterile vessels are produced,

- Plants that their seeds have germination and growing problems such as orchids and nepenthes, can be easily produced, 
- $\quad$ Providing infection-free plants for mass production is possible.

Plant tissue culture is based on totipotency which means that a whole plant can be regenerated from a single cell on a growth medium. One of the main objectives of tissue culture studies is to obtain high-frequency shoot regeneration, which is also a prerequisite for an efficient transformation system and a clonal propagation of plants with attractive flowers and fruits in large scale for ornamental purposes. Specially the introduction of foreign genes coding agronomically important traits into plant cells has no meaning unless transgenic plants are regenerated from the genetically modified cell(s).

It is known that some families and genera such as Solanacea (Nicotiana, Petunia and Datura), Cruciferae (Brassica and Arabidopsis), Gesneriaceae (Achimenes and Streptocarpus), Asteraceae (Chichorium and Chrysanthemum) and Liliaceae (Lilium and Allium) have a high regeneration capacity while regeneration in some other families such as Malvaceae (Gossypium) and Chenopodiaceae (Beta) is difficult. In order to increase the regeneration capacity of explant from the genotype of interest, we have to find answers to such questions as "Why do some genotypes regenerate easily?", "What can be done to increase the regeneration capacity of explant?".

\section{Factors affecting explant's regeneration capacity}

\subsection{Plant material}

Plant material is extremely important for the success of tissue culture studies [4]. Factors affecting explant's tissue culture response are (1) genotype, (2) physiological stage of donor plant, (3) explant source, (4) explant age, (5) explant size, (6) explant position in donor plant and (7) explant density. Plant segments used in tissue culture as explant are stem [5], root [6], leaf [7], flower [8], ovule [9], cotyledon and hypocotyl [10, 11]. Such these explants form direct and indirect organs and embriyos. Thin cell layer can also be used as explant in some species [12] while embryos can be successfully used in cereals [13]. Moreover, shoot tips and meristems may give successful results for callus formation and shoot regeneration [14].

\subsubsection{Genotype}

Regeneration capacity of plants shows a wide range among families, species and even within genotypes from the same species (Figure 1). Generally dicotyledons regenerate more easily than monocots. Plants from some dicotyledon families such as Solanacea, Cruciferae, Gesneriaceae, Begoniaceae and Crassulaceae have a high regeneration capacity. In general, herbaceous plants regenerate more easily than woody plants such as trees and shrubs [3].

Sugarbeet from Chenopodiaceae family is known as a recalcitrant genotype with respect to in vitro culture and genetic transformation [15, 16] (Figure 2) while regeneration and transformation are quite easy in tobacco from Solanaceae family [17]. It was reported that somatic embryogenesis changed from $0.00 \%$ to $77.50 \%$ in 14 maize genotypes cultured in vitro [18]. 

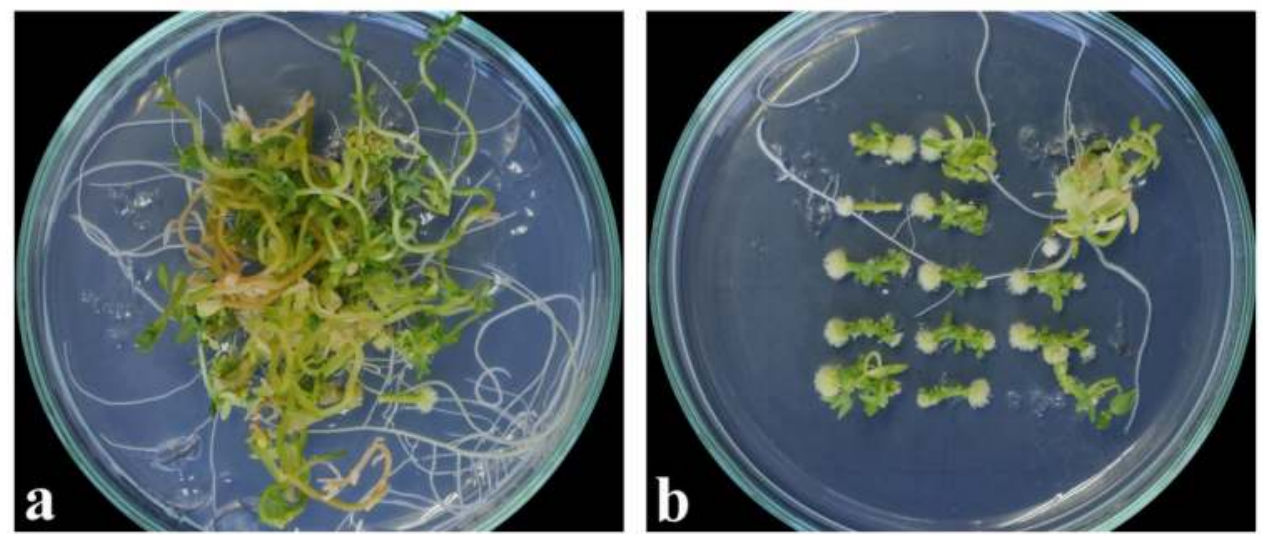

Figure 1. Adventitious shoot regeneration from hypocotyl explants of flax (Linum usitatissimum L.) cultivars a. '1886 Sel.' and b. 'Clarck' 4 weeks after culture initiation

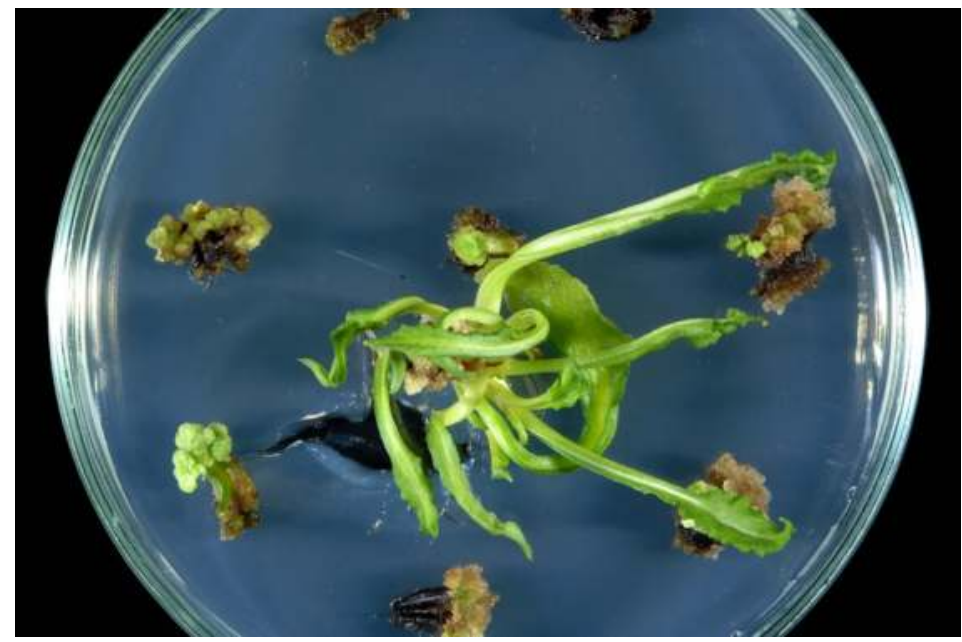

Figure 2. Shoot regeneration from petiole explants of sugar beet (Beta vulgaris L.) 4 weeks after culture initiation. Only three explants out of 10 regenerated.

\subsubsection{Physiological stage of donor plant}

Explants show an ability to express totipotency are the most suitable for tissue culture [19]. Generally, vegetative segments of plants regenerate more easily in vitro than generative ones [20]. Explants should be isolated from healthy plants with high cell division for successfull response to tissue culture. On the other hand, regeneration capacity of mature tissues is quite low. In general, young tissues and organs have a high 
regeneration capacity than the older ones. Regeneration capacity of genotypes increases during flowering period as in Lunaria annua [21], Ranunculus sceleratus [22]. Although plants in a resting stage (dormant) are generally difficult to culture in vitro [3], there are some exceptions as flower stem explants of Tulipa form shoots only in dry storage (dormant) stage [23].

\subsubsection{Explant source}

Plants grown under greenhouse conditions give rise to better results than the ones grown in field conditions [24]. There are huge variations regarding tissue culture response in explants excised from plants grown in field condition depending on wheather conditions during the year [3]. However, the best results are obtained from explants excised from in vitro grown seedlings [25].

In a study conducted by Yildiz et al. [25], regeneration capacity of flax (Linum usitatissimum L.) hypocotyl explants isolated from in vitro- and greenhouse-grown seedlings was compared. Five mm sections of hypocotyl explants from in vitro-grown seedlings were directly cultured on MS medium supplemented with $1 \mathrm{mg} \mathrm{l}^{-1} \mathrm{BAP}$ and $0.02 \mathrm{mg} \mathrm{l}^{-1} \mathrm{NAA}$ for shoot regeneration while hypocotyls from greenhouse-grown seedlings were surfacesterilized before culture initiation. The highest values with respect to shoot regeneration percentage, shoot number per explant and total shoot number per petri dish were recorded in explants isolated from in vitro-grown seedlings of all cultivars.

87.50 shoots were formed over 100.00 in explants isolated from in vitro-grown seedlings while only 22.50 shoots were recoved in explants of greenhouse-grown seedlings in cv. '1886 Sel.'. The highest shoot number per explant and total shoot number per petri dish were obtained in explants isolated from in vitro-grown seedlings as 14.43 and 126.26, respectively. Specially, total shoot number per petri dish was 42.95 times more in explants of in vitrogrown seedlings as 126.26 than in explants excised from greenhouse-grown seedlings as 2.94. It was reported that neither shoot regeneration percentage nor shoot number per explant is lonely an indicator of the success of tissue culture studies but 'total shoot number per petri dish' is a good indicator of the success in both parameters for the genotype of interest [26]. These figures in all the parameters indicated the significance of explant source very well.

\subsubsection{Explant age}

Regeneration capacity of older plants is often low. As the organ using for explant source gets older, regeneration capacity decreases. An example of differences in regeneration capacity between young and old seedlings that are used as source of explant was flax (Linum usitatissimum L.) [27]. In this study, shoot regeneration capacity of hypocotyl explants excised from in vitro-grown seedlings at different ages (7,12 and 17 days) was examined in three flax cultivars. Explants of 7-day-old seedlings gave rise to the highest results with 
respect to shoot regeneration percentage, shoot number per explant and total shoot number per petri dish. The explants of 7-day-old seedlings were reported to be more vital and well grown (Figure 3).
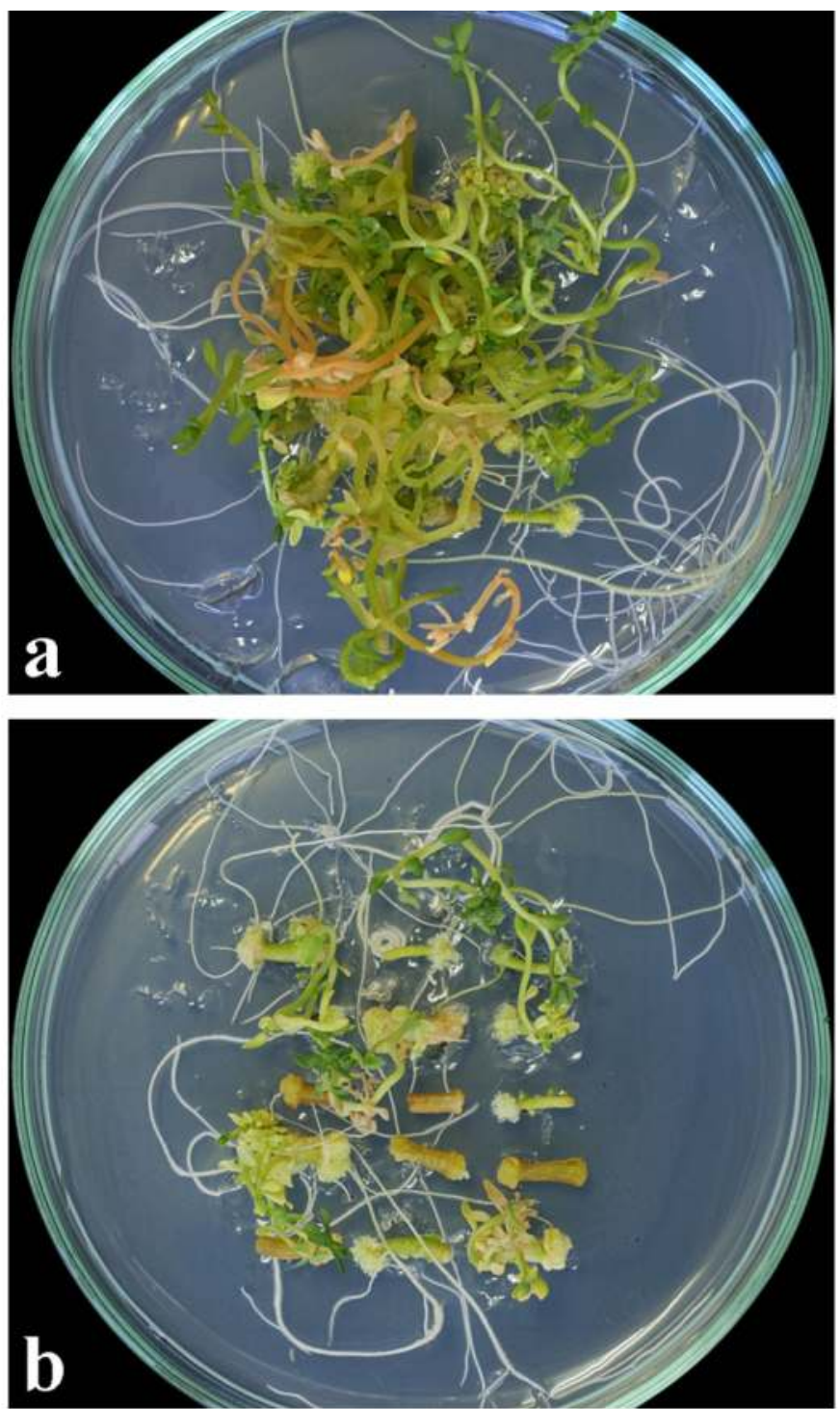

Figure 3. Shoot regeneration from flax (Linum usitatissimum L.) cv. '1886 Sel.' hypocotyl explants excised from a. 7-day-old seedling and b. 12-day-old seedling 4 weeks after culture initiation 
In the study, it was observed that shoot regeneration percentage, shoot number per explant and total shoot number per petri dish varied excessively among explants from different seedling ages. All these three parameters, which were the highest in explants of 7-day-old seedling were reduced significantly in explants of 12- and 17-day-old seedlings. Results clearly showed that there were statistically significant differences in all parameters examined in all cultivars among explants at different ages.

\subsubsection{Explant size}

It is so difficult to obtain a successful tissue culture response from small parts such as cells and meristems than from larger parts such as leaves and hypocotyls due to their limited nutrients and hormone reserves. Larger explants having a big amount of nutrition reserves such as tubers and bulbs can easily regenerate in vitro and are less dependent on nutrients and hormones in growth medium [3].

\subsubsection{Explant position in donor plant}

In vitro growth of explants can be affected depending on the place from where they are excised. For instance, the higher parts of donor plant are older than the lower parts. Evers [28] has reported that shoot initials from lower parts of Pseudotsuga menziesii developed better under in vitro conditions. Explants excised from the base produce adventitious bulbs more easily than the top parts of the bulbs [3].

In a study conducted with flax, tissue culture response of hypocotyl explants at different positions was evaluated. Hypocotyls were classified from where they were excised as top, medium and low. Top part was just below the cotyledon leaves while lower one was close to bottom (Figure 4). Fifteen hypocotyls from 7-day-old in vitro-grown seedlings were cultured on MS medium $1 \mathrm{mg} \mathrm{l}^{-1} \mathrm{BAP}$ and $0.02 \mathrm{mg} \mathrm{l}^{-1} \mathrm{NAA}$ for 4 weeks.

Explants excised from top (just below cotyledon leaves) part of the seedling gave rise to the highest results with respect to shoot regeneration percentage, shoot number per explant and total shoot number per petri dish. Results were getting lower in the explants excised from medium part of the seedling. And the lowest values were recorded in the explants from lower part (Unpublished study results) (Figure 5).

The highest values in shoot regeneration percentage, shoot number per explant and total shoot number per petri dish were recorded in the explants excised from the top of the seedling as $97.78 \%, 5.17$ and 76.00 , respectively. These figures were the lowest in hypocotyl segments in the lower part of the seedling as $66.67 \%, 2.62$ and 26.33 , respectively. There were huge difference between the results of explants excised from the top and the low parts of the seedling. Shoot regeneration percentage was $97.78 \%$ in explants of the top part of the seedling while it was $66.67 \%$. That is 97.78 explants regenerated over 100.00 in the top part of the seedling. 
Mean shoot number per explant was recorded as 5.17 in explants excised from the top parts of the seedling while it was 2.62 in explants isolated from the low part of the seedling. Similar results were obtained in total shoot number per petri dish. Shoot number per explant and total shoot number per petri dish are the main indicators of success in plant tissue culture. Especially, after transformation studies via Agrobacterium tumefaciens, regeneration capacity of tissue decreases siginificantly due to plant defense mechanism against pathogen attact. That is why, the number of shoots regenerated should be as much as possible.

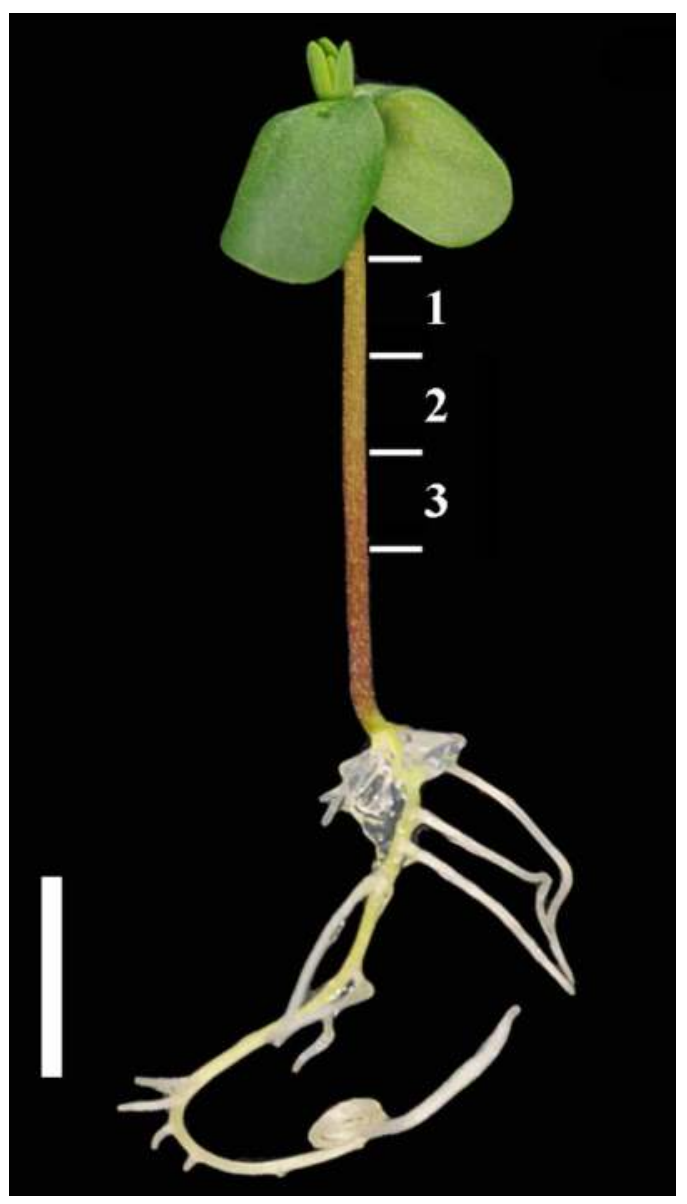

Figure 4. Seven-day-old flax (Linum usitatissimum L.) cv. 'Madaras' seedling and the position from which explants were excised 1 . top, 2 . medium and 3 . low. Bar $=1.0 \mathrm{~cm}$ 

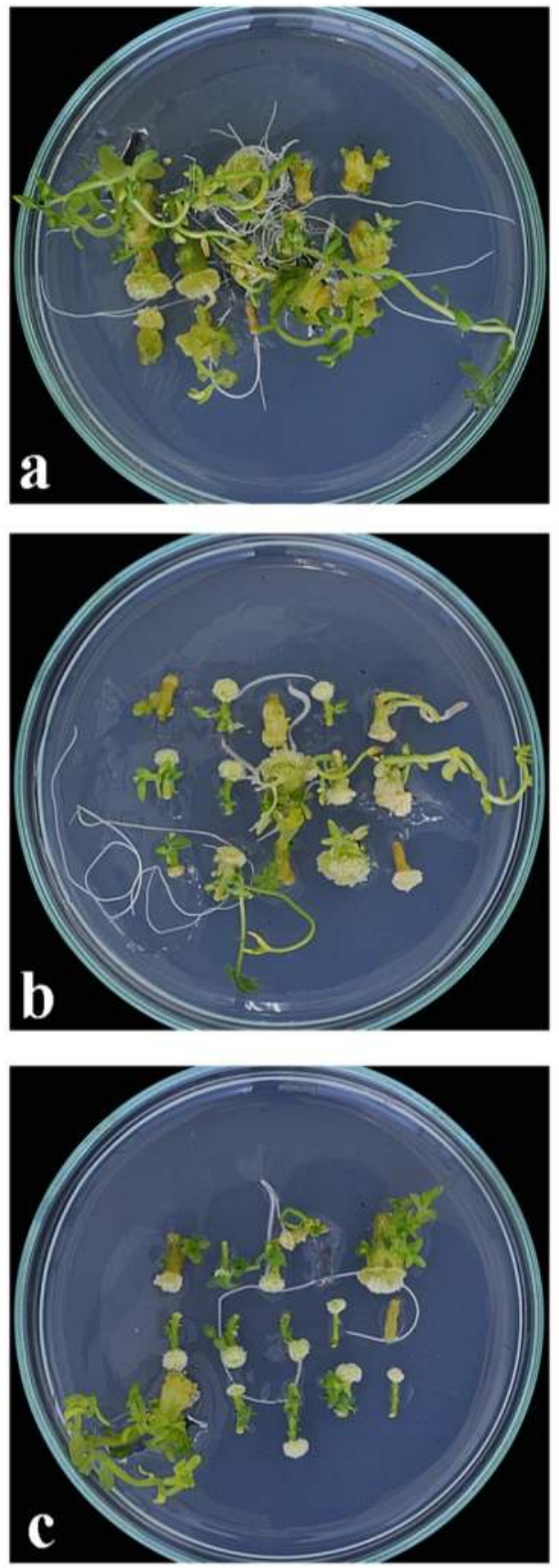

Figure 5. Tissue culture response of hypocotyl explants excised from different positions of flax (Linum usitatissimum L.) cv. 'Madaras' seedling a. top, b. medium and c. low 


\subsubsection{Explant Density}

There are many studies about competition among the plants in field conditions. Plant leaves compete for irradiance, and roots for water and nutrients $[29,30]$. High plant density was accepted as a biotic stress factor [31, 32]. Stoffella and Bryan [33] have reported that plant density has an effect on plant development and yield of many vegetable crops. A linear increase has indicated in fruit yield when plant density is increased [34-36]. Abubaker [37] has noted that the highest planting density gave rise to the lowest yield in bean due to the high competition among plants for water and minerals. Asghari et al. [38] have reported that the chicory plant increased root diameter for increased absoption of water under high density by high competition between plants.

Since a plant is a unity of cells and tissues, behavior of cells and tissues as the smallest unit of the organism, represents the plant's response against any factors arising from nearby environment. Competition and stress are the brother concepts that should be taken into account to increase the success of tissue culture studies. Explants under in vitro conditions compete with each other for a constant amount of water and nutrients in growth medium. It was revealed that competition was one of the most important factors increasing explant's regeneration capacity [32].

Yildiz [32] has reported that encouraging hypocotyl explants of flax (Linum usitatissimum L.) for competition by decreasing the culture distances among them increased shoot regeneration capacity remarkably till a certain point from where stress initiated and significant decreases in all parameters were observed (Figure 6 and Figure 7). For shoot regeneration, hypocotyls were cultured in a petri dish $(90 \times 90 \mathrm{~mm})$ at $0.5 \times 0.5,1.0 \times 1.0,1.5$ $\mathrm{x} 1.5$ and $2.0 \times 2.0 \mathrm{~cm}$ distances.

Results clearly showed that there were statistically significant differences in fresh and dry weights in all cultivars among explants cultured at different culture distances. The highest fresh and dry weights per explant of all cultivars were obtained from $2.0 \times 2.0 \mathrm{~cm}$ distance of hypocotyls and they decreased by decreasing distances. These findings were supported by Gersani et al. [39] and Maina et al. [40] who reported that plants grown alone produce more biomass or yield than those grown with the others. It could be concluded that the decreased distance in which explants were cultured induced stress caused likely by the deficiency of water, sucrose and nutrients. Increases in the fresh and dry weights were chiefly due to an increase in the absorption of water and other components from the basal medium [41]. It was stated that the fresh weight increase was mainly due to cell enlargement by water absorption [42] and increase in dry weight was closely related to cell division and new material synthesis [43].

The highest shoot number per hypocotyl (20.70 in 'Madaras', 14.57 in '1886 Sel.' and 17.40 in 'Clarck') and the highest shoot length (3.10, 2.14 and $2.09 \mathrm{~cm}$, respectively) were obtained at $1.0 \times 1.0 \mathrm{~cm}$ distance in all cultivars studied. It is thought that competition among explants cultured at $1.0 \times 1.0 \mathrm{~cm}$ distance encouraged them to give higher results than at the other distances. 
Plant growth regulators are perhaps the most important components affecting shoot regeneration capacity of explants [44]. In tissue culture studies, correct combinations of auxins and cytokinins have been tried to be determined for high frequency shoot regeneration for the explant [26]. This study has shown that determination of optimum levels of auxins and cytokinins in growth medium is not the only way of increasing shoot regeneration capacity, but also shoot regeneration frequency of explants could be increased simply by encouraging explants into competition.
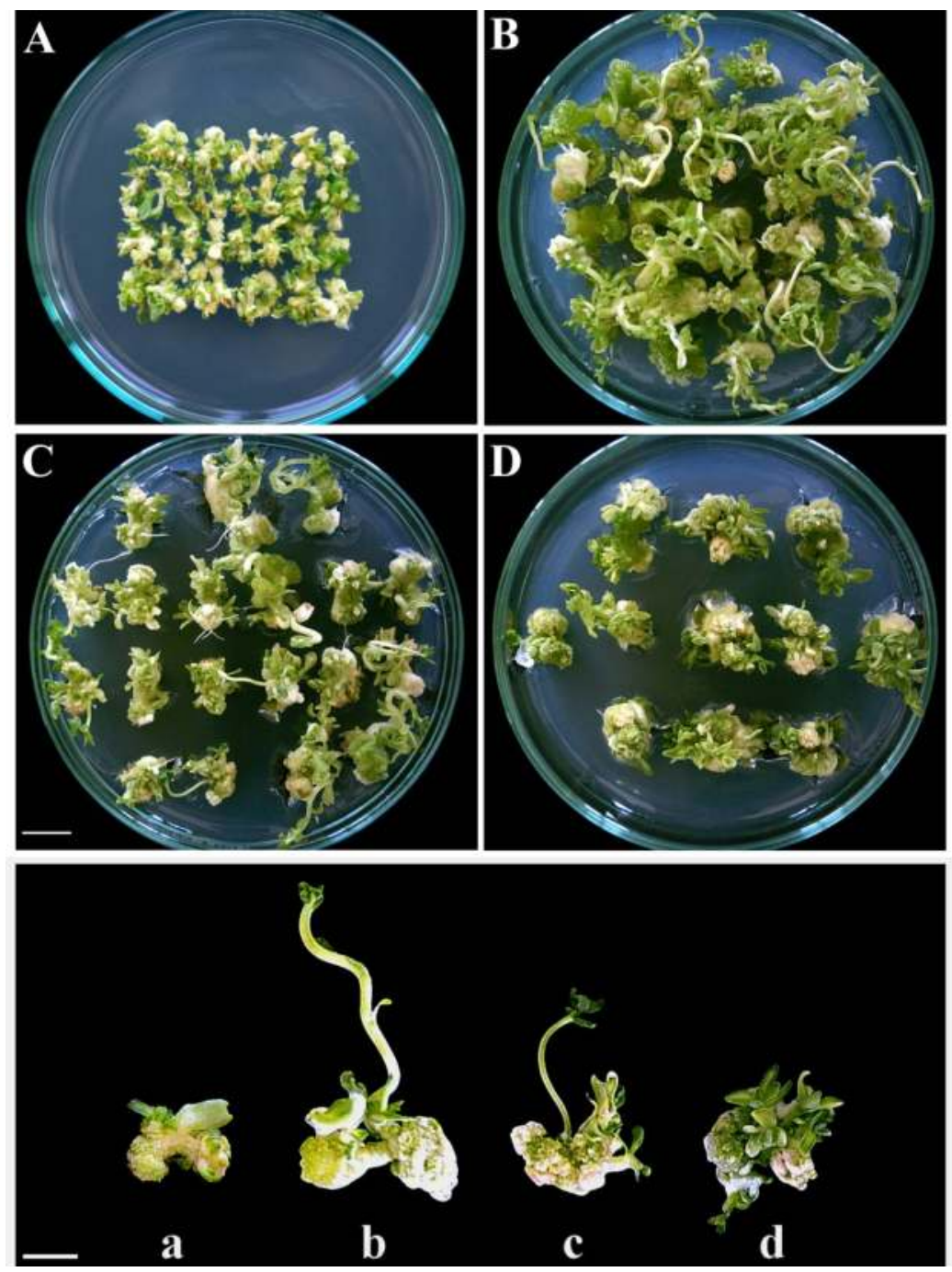

Figure 6. Development of explants cultured at different distances $0.5 \times 0.5 \mathrm{~cm}(\mathrm{~A}, \mathrm{a}), 1.0 \times 1.0 \mathrm{~cm}(\mathrm{~B}, \mathrm{~b})$, $1.5 \times 1.5 \mathrm{~cm}(\mathrm{C}, \mathrm{c})$ and $2.0 \times 2.0 \mathrm{~cm}(\mathrm{D}, \mathrm{d})$; six weeks after culture initiation. Bar is $1.0 \mathrm{~cm}$ for petri dishes and $0.5 \mathrm{~cm}$ for shoot regeneration 

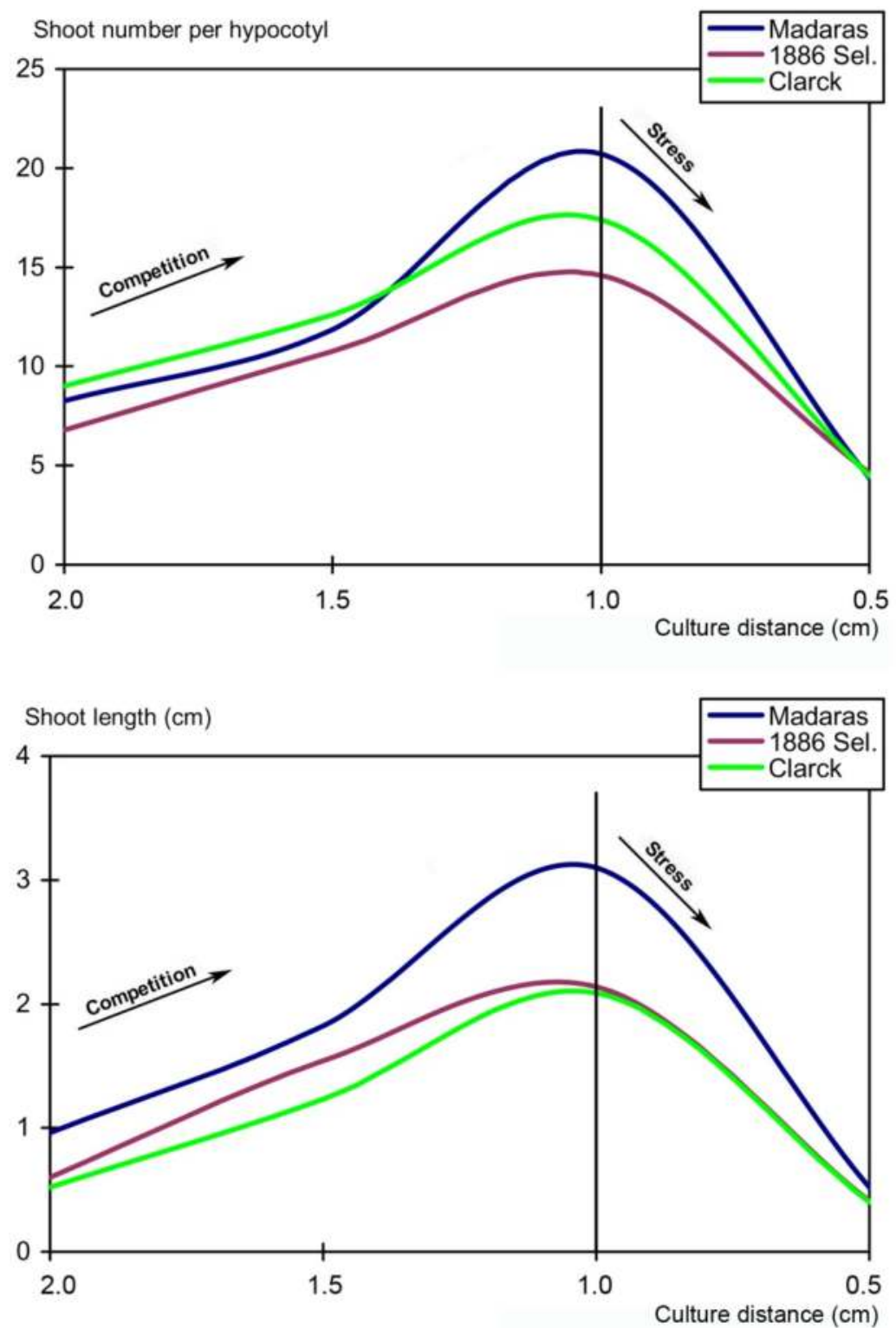

Figure 7. Competition-stress curve of flax cultivars 'Madaras', '1886 Sel.' and 'Clarck' with respect to shoot number per hypocotyl and shoot length

\subsection{Surface-sterilization process}

All tissue culture studies which aim to obtain high-frequency shoot regeneration, which is also a prerequisite for an efficient transformation system, should be performed under sterile 
conditions. Explant health is the main factor determining regeneration capacity. Viability of explant and the seedling from which the explant is excised, are very important for highfrequency shoot regeneration [45]. The most important treatment prior to culture initiation is perhaps surface-sterilization of the explant. Since in vitro conditions provide bacteria and fungi with an optimal growth environment, unsuccessful sterilization hinders the progress of tissue culture studies. Surface-sterilization process aims to eliminate all microorganisms that can easily grow under in vitro conditions; on the other hand, it should guarantee the explant's viability and regeneration capacity, which are known to be affected by the concentration, application period [46] and temperature [45] of disinfectant. Since direct contact of explant with disinfectant during the sterilization process may have a severe effect on regeneration capacity of the tissue [45], using aseptic tissues as source of explant is highly recommended $[47,48]$.

A wide range of surface disinfectants, such as ethanol, hydrogen peroxide, bromine water, mercuric chloride, silver nitrate, and antibiotics are used for surface-sterilization; however sodium hypochlorite $(\mathrm{NaOCl})$ has been most widely used. $\mathrm{NaOCl}$ is highly effective against all kinds of bacteria, fungi, and viruses [49-52]. Moreover, $\mathrm{NaOCl}$ has a strong oxidizing property which makes it highly reactive with amino acids [53, 54], nucleic acids [55], amines, and amides [56,57]. The general reaction between amino acids and $\mathrm{NaOCl}$ produces the respective aldehyde, $\mathrm{NH}_{4} \mathrm{Cl}$ and $\mathrm{CO}_{2}[54]$.

\subsubsection{Effect of sodium hypochlorite solutions at different concentrations and application periods}

In vitro seed germination, seedling growth and the viability of the tissue were negatively affected by sodium hypochlorite $(\mathrm{NaOCl})$ at high concentrations $[45,58,59]$ while it is uneffective for sterilization of tissues at low concentrations. The negative effects of $\mathrm{NaOCl}$ concentration become more severe with increasing application period. Since regeneration capacity of the tissue is negatively affected by higher concentrations and longer application periods of disinfectants [3,46], sterilization process under in vitro conditions should aim to use the lowest concentration of disinfectant for the shortest time.

In the study aiming to evaluate the effects of $\mathrm{NaOCl}$ solutions used for sterilization on in vitro seed germination and seedling growth in Lathyrus chrysanthus Boiss., the best results were obtained from $3.75 \% \mathrm{NaOCl}$ concentration and $15 \mathrm{~min}$. application period for all parameters examined [60]. Seedborne contamination increased gradually by decreasing concentrations and application periods of $\mathrm{NaOCl}$ below $3.75 \%$ and 15 min. Dramatic decreases were observed at $5.00 \% \mathrm{NaOCl}$ concentration in all cases. At this concentration, $\mathrm{NaOCl}$ showed deleterious effect on the embryo of the seed. Seed germination decreased to $65.18 \%$ when $\mathrm{NaOCl}$ concentration increased to $5.00 \%$ from $3.75 \%$ at $15 \mathrm{~min}$. application period. Seedling growth from seeds sterilized with $3.75 \% \mathrm{NaOCl}$ concentration for 15 min. were observed growing faster than that of sterilized with other concentrations and application periods of $\mathrm{NaOCl}$ (Figure 8). By increasing $\mathrm{NaOCl}$ concentration to $5.00 \%$, seedling length decrased to $3.45 \mathrm{~cm}$ from $3.90 \mathrm{~cm}$. Higher results in seedlings grown from 
seeds sterilized with $3.75 \% \mathrm{NaOCl}$ concentration for $15 \mathrm{~min}$. could be caused by higher tissue water content as reported that in vitro explant growth and plantlet establishment have been affected significantly by tissue water content [41].

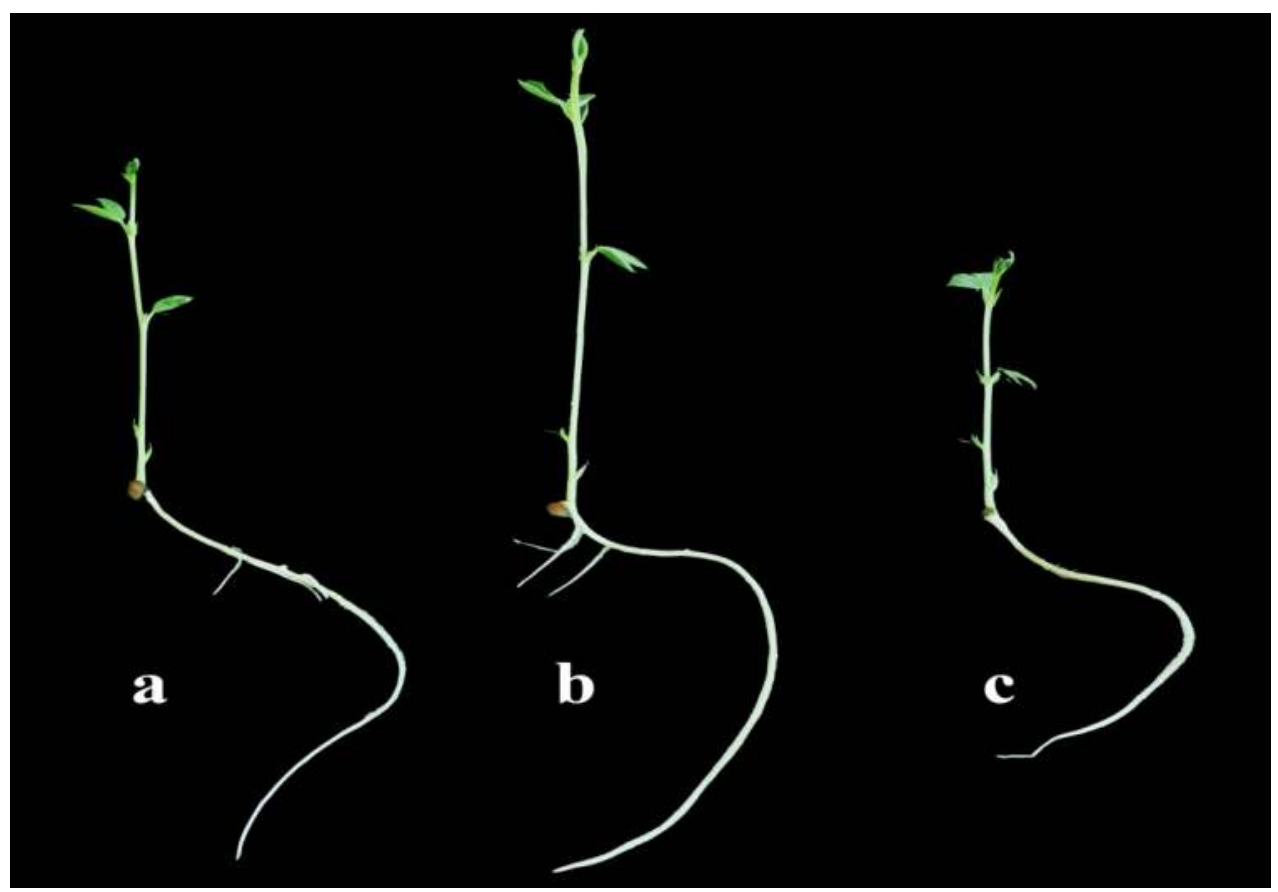

Figure 8. In vitro seedling growth from Lathyrus chrysanthus seeds sterilized with (a) $2.50 \%$,

(b) $3.75 \%$ and (c) $5.00 \% \mathrm{NaOCl}$ for $15 \mathrm{~min}$.

\subsubsection{Effect of sodium hypochlorite solutions at different temperatures}

It was firstly reported that besides concentration and application period, temperature of $\mathrm{NaOCl}$ was also one of the most important factors affecting in vitro seed germination, seedling growth and explant's regeneration capacity [45].

At the $2.00 \% \mathrm{NaOCl}$ concentration using for surface-sterilization of flax (Linum usitatissimum L.) seeds, when the temperature of $\mathrm{NaOCl}$ was set below $10^{\circ} \mathrm{C}$, bacterial and fungal contamination was observed. However, increases in $\mathrm{NaOCl}$ temperature above $10^{\circ} \mathrm{C}$ resulted in dramatic decreases in seed germination, seedling growth, hypocotyl and root lengths. When flax seeds were surface-sterilized with $3.00 \%$ and $4.00 \% \mathrm{NaOCl}$ concentrations at $30^{\circ} \mathrm{C}$, seed germination, seedling growth, hypocotyl and root lengths decreased dramatically. Decreases in all parameters in $\mathrm{NaOCl}$ temperature above $10^{\circ} \mathrm{C}$ could be the fact that disinfection activity of $\mathrm{NaOCl}$ increases [61] and disinfectant penetrates more easily through the seed coat [62]. Higher $\mathrm{NaOCl}$ temperatures resulted in morphologically abnormal seedlings with stunted hypocotyls and roots (Figure 9). 
Yildiz and Er [45] reported that increasing disinfectant temperature using for surfacesterilization of flax seeds to obtain sterile in vitro seedlings from which hypocotyls were isolated, reduced shoot regeneration significantly.

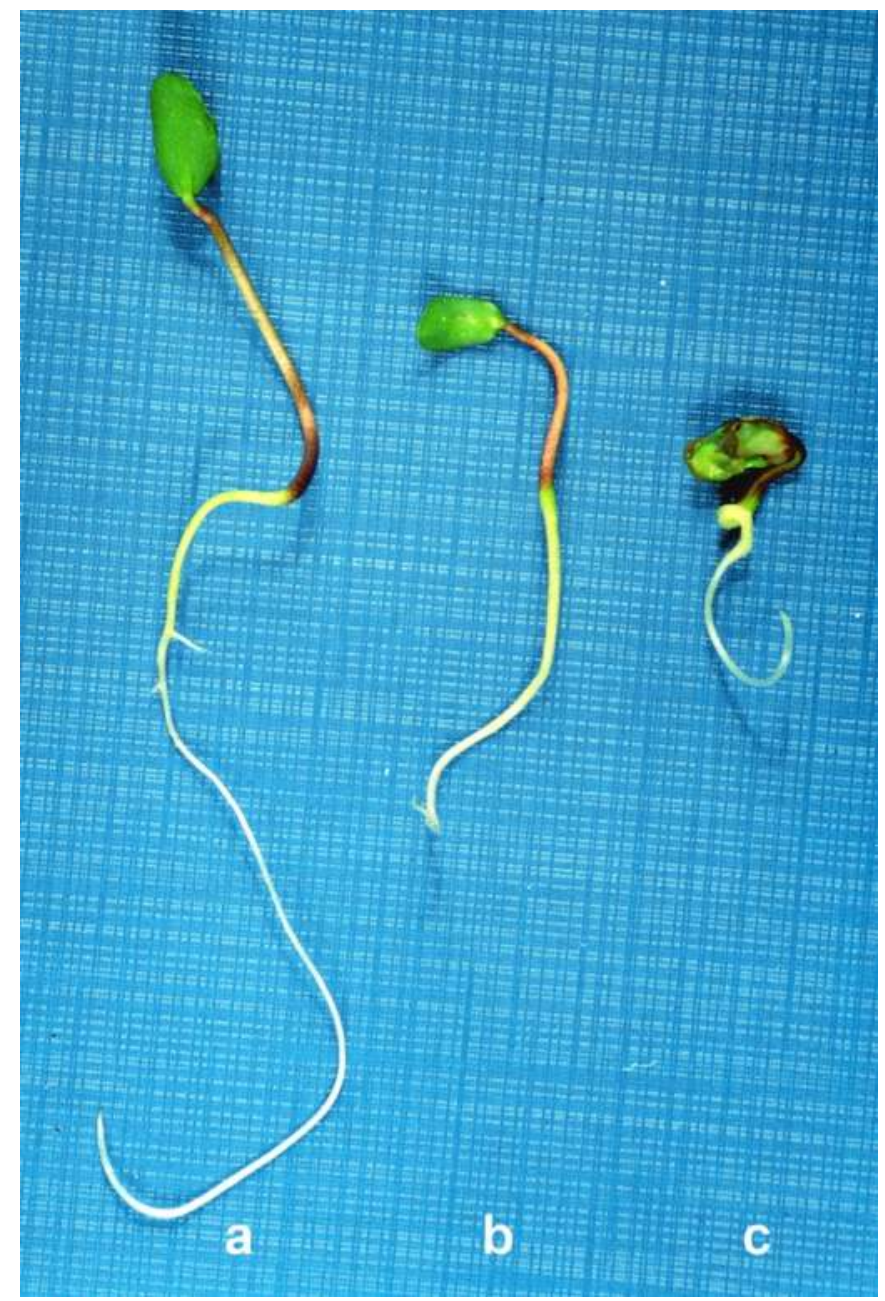

Figure 9. In vitro seedling growth in flax from seeds sterilized with $2.00 \% \mathrm{NaOCl}$ at temperatures of (a) $10^{\circ} \mathrm{C}$, (b) $20^{\circ} \mathrm{C}$ and (c) $30^{\circ} \mathrm{C}$

Regeneration capacity of the explant is negatively affected by higher concentrations, application periods and temperatures of disinfectant used for surface-sterilization. In the sterilization process of the tissues, the concentration, application period and temperature of $\mathrm{NaOCl}$ solutions are closely related to each other and they should be considered together. Direct contact of the tissue with disinfectant during the sterilization process may have a severe effect on the viability and regeneration capacity depending on concentration, 
temperature and application periods of disinfectant $[45,46]$. In addition to this common knowledge, not only seed germination and seedling growth are directly affected by sterilization process, but also regeneration capacity of explants and health of regenerated shoots are indirectly influenced significantly in plant tissue culture studies. That means $\mathrm{NaOCl}$ affects the success of in vitro studies, from in vitro seed germination and seedling establishment to regeneration capacity of the tissue and recovery of plantlets.

\subsection{Culture medium}

The composition of growth medium is an important factor affecting growth and morphogenesis of plant tissues. Plant tissue culture medium consists of macronutients, micronutrients, vitamins, amino acids or other nitrogen supplements, carbon sources, organic supplements, solidifying agents and growth regulators. Murashige and Skoog [63] are the most commonly used medium in plant tissue culture. The B5 [64], N6 [65] and Nitsch and Nitsch [66] (NN) have been widely used for many plant species. Moreover, for culture of woody species, the Driver/Kuniyuki walnut medium (DKW) [67] and the WPM medium [68] are used. The growth medium is selected for the purpose of tissue culture and for the plant species [69].

Yildiz et al. [27] have conducted a study to evaluate the effects of two different growth medium (MS and B5) and two gelling agents (Agar and Phytagel) on the regeneration capacity of flax (Linum usitatissimum L.) hypocotyl explants of three cultivars namely 'Madaras', '1886 Sel.' and 'Clarck'. Results showed that MS (Murashige and Skoog) growth medium and Agar as gelling agent gave rise to the highest results with respect to shoot regeneration percentage, shoot number per explant and total shoot number per petri dish in all cultivars studied (Table 1).

\begin{tabular}{ccccc|cccccccc}
\hline \multirow{2}{*}{ Cultivars } & \multicolumn{4}{c|}{ Shoot regeneration (\%) } & \multicolumn{4}{c|}{ Shoot number per explant } & \multicolumn{3}{c}{ Total shoot number per petri dish } \\
\cline { 2 - 13 } & 1 & 2 & 3 & 4 & 1 & 2 & 3 & 4 & 1 & 2 & 3 & 4 \\
\hline 'Madaras' & 97.22 & 91.67 & 80.56 & 91.67 & $7.41 \mathrm{a}$ & $4.70 \mathrm{~b}$ & $2.56 \mathrm{~cd}$ & $2.50 \mathrm{~cd}$ & $86.67 \mathrm{a}$ & $56.34 \mathrm{bc}$ & $30.67 \mathrm{cde}$ & $30.00 \mathrm{cde}$ \\
\hline '1886 Sel.' & 100 & 100 & 100 & 100 & $6.72 \mathrm{a}$ & $5.56 \mathrm{ab}$ & $4.14 \mathrm{~cd}$ & $3.95 \mathrm{~cd}$ & $80.34 \mathrm{a}$ & $66.67 \mathrm{ab}$ & $49.67 \mathrm{~cd}$ & $47.34 \mathrm{~cd}$ \\
\hline 'Clarck' & 97.22 & 88.89 & 88.89 & 94.44 & $4.81 \mathrm{a}$ & $3.02 \mathrm{~b}$ & $2.59 \mathrm{bc}$ & $2.34 \mathrm{bc}$ & $57.67 \mathrm{a}$ & $35.00 \mathrm{~b}$ & $31.00 \mathrm{bc}$ & $28.00 \mathrm{bcd}$ \\
\hline
\end{tabular}

1. MS medium and Agar; 2. MS medium and Phytagel; 3. B5 medium and Agar; 4. B5 medium and Phytagel Values in a row for each cultivar followed by the different letters are significantly different at the 0.01 level

Table 1. The effect of different growth medium and gelling agents on shoot regeneration capacity of flax hypocotyl explants

\subsection{Culture conditions}

After explants placed on growth medium for different purposes, they should be cultured in culture rooms where the environmental factors such as temperature and light are controlled. Different species may need different environmental conditions for successful culture.

Lighting in culture rooms is realized by fluorescent tubes. Control equipments of tubes should be set up outside the culture room. Otherwise they may cause over heating inside 
the room and in that case extra cooling is necessary. Due to light sources inside the culture room, there should be an efficient cooling system to maintain constant temperature conditions. Fluorescent tubes can be installed under the shelves, above the cultures which provide a more uniform irradiation for the cultures. Although $16 \mathrm{~h}$ light and $8 \mathrm{~h}$ dark photoperiod is usually used, there may be some differences according to species grown under long-day or short-day conditions.

The temperature in culture room is so important for successful tissue culture. Temperature variation in culture room should be as small as possible and generally $\pm 1^{\circ} \mathrm{C}$ is allowed. Otherwise, changing temperature regime causes stress in cultures which is one of the main reasons of unsuccess. That is why, working with many culture rooms are recommended instead of working only with one.

\section{Treatments increasing explant's regeneration capacity}

\subsection{Increasing tissue water content}

Water is the source of life on earth. Life in a large proportion of terrestrial ecosystems is limited by water availability. The water content of an actively growing plant can be as much as $95 \%$ of its live weight. A plant requires water as an essential ingredient of photolysis, the photochemical stage of photosynthesis where water is split using light energy. Neither carbon dioxide nor oxygen required for photosynthesis is usable by plant unless it is in solution in water. Therefore, water is the key to plant's survival and growth. Water is also an excellent solvent. The substances (solutes) that become dissolved in water in plants include mineral ions such as potassium $\left(\mathrm{K}^{+}\right)$, sugars (glucose and sucrose), and amino acids, main components of proteins.

The reduction in growth, yield and quality by water stress has been well recognized in field conditions [70-71]. Germination and seedling establishment guarantee plant survival and are very important phases of plant life. Germination rate decreases with decreasing external water potential and for each species there is a critical value of water potential below which germination will not occur [72].

Yildiz and Ozgen [41] have reported that tissue water content affected explant's shoot regeneration capacity significantly. In the study, water-treated and non-water treated hypocotyl explants of three flax cultivars were compared with regard to fresh and dry weights, shoot regeneration percentage, shoot number per explant, shoot length and total shoot number per petri dish. Some hypocotyls were submerged in sterile distilled water with a gentle shaking for $20 \mathrm{~min}$ before placing on regeneration medium, while others were directly cultured on MS medium supplemented with $1 \mathrm{mg} \mathrm{l}^{-1}$ 6-benzylaminopurine (BAP) and $0.02 \mathrm{mg} \mathrm{l}^{-1}$ naphthaleneacetic acid (NAA) for regeneration. Results clearly showed that there were sharp and statistically significant differences in all cultivars between water-treated and non-water-treated explants concerning all characters examined (Table 2, Figure 10). 
Possibly, pretreatment of explants with water softened the epidermis layer and increased the permeability which caused to high tissue metabolic activity by increasing water and hormone uptake from the medium. Thus, increase in the fresh and dry weights of watertreated hypocotyl explants at the end of culture were chiefly due to an increase in the absorption of water and other components from the basal medium via high permeable epidermis membrane. In the study, non-water-treated explants were found smaller than water-treated ones in all cultivars. Dale [42] stated that the fresh weight increase is mainly due to cell enlargement by water absorption, cell vacuolation, and turgor-deriven wall expansion. The increase in dry weight was closely related to cell division and new material synthesis [43]. Dry weight increase of water-treated explants is due to an increase in carbohydrate metabolism resulting from increased water uptake. On the other hand, lower levels of all parameters of non-water-treated explants were directly due to a decreased water uptake from the environment and consequently, a reduced mobilization of plant growth regulators. Hsiao [73] has reported that the inhibition of growth under water stress conditions is the result of inhibition of cell division, cell elongation or both. Osmotic water absorption affects cell elongation. It has been suggested that osmotic stress modifies the biochemical changes taking place in the cell wall during growth thereby preventing extension [74]. The primary action of osmotic inhibition is retardation of water uptake which is vital for germination and growth [75]. It has been stated that water stress alters the level of plant hormones [76].

\begin{tabular}{|c|c|c|c|c|c|c|}
\hline \multirow{3}{*}{ Cultivar } & \multicolumn{4}{|c|}{ Hypocotyl } & \multirow{2}{*}{\multicolumn{2}{|c|}{ Shoot regeneration $(\%)$}} \\
\hline & \multicolumn{2}{|c|}{ Fresh weight (g) } & \multicolumn{2}{|c|}{ Dry weight (g) } & & \\
\hline & WT & NWT & WT & NWT & WT & NWT \\
\hline 'Madaras' & $0.430 \pm 0.047$ & $0.216 \pm 0.019$ & $0.034 \pm 0.002$ & $0.025 \pm 0.002$ & $100 \pm 0.000$ & $75.00 \pm 2.937$ \\
\hline '1886 Sel.' & $0.343 \pm 0.011$ & $0.231 \pm 0.013$ & $0.029 \pm 0.013$ & $0.021 \pm 0.001$ & $100 \pm 0.000$ & $73.34 \pm 4.051$ \\
\hline 'Clarck' & $0.396 \pm 0.013$ & $0.192 \pm 0.025$ & $0.031 \pm 0.001$ & $0.019 \pm 0.002$ & $100 \pm 0.000$ & $78.33 \pm 2.305$ \\
\hline \multirow[t]{2}{*}{ Cultivar } & \multicolumn{2}{|c|}{$\begin{array}{c}\text { Shoot number per } \\
\text { hypocotyl }\end{array}$} & \multicolumn{2}{|c|}{ Shoot length (cm) } & \multicolumn{2}{|c|}{$\begin{array}{c}\text { Total shoot number per } \\
\text { petri dish }\end{array}$} \\
\hline & WT & NWT & WT & NWT & WT & NWT \\
\hline 'Madaras' & $12.17 \pm 0.210$ & $8.00 \pm 0.328$ & $0.56 \pm 0.043$ & $0.25 \pm 0.018$ & $182.50 \pm 3.142$ & $119.88 \pm 4.90$ \\
\hline '1886 Sel.' & $11.20 \pm 0.114$ & $8.15 \pm 0.367$ & $0.58 \pm 0.029$ & $0.22 \pm 0.009$ & $167.88 \pm 1.712$ & $122.25 \pm 5.487$ \\
\hline 'Clarck' & $10.83 \pm 0.265$ & $5.26 \pm 0.491$ & $0.60 \pm 0.043$ & $0.27 \pm 0.020$ & $162.50 \pm 3.974$ & $78.88 \pm 7.392$ \\
\hline
\end{tabular}

In all cases, the values for WT and NWT were significantly different at 0.01 level with the exception of dry weight of hypocotyls of Madaras which is different at 0.05

Table 2. Adventitious shoot regeneration from water-treated (WT) and non-water-treated (NWT) hypocotyls of three flax cultivars 6 weeks after culture initiation on MS medium containing $1 \mathrm{mg} \mathrm{l}^{-1} \mathrm{BAP}$ and $0.02 \mathrm{mg} \mathrm{l}^{-1} \mathrm{NAA}$.

Treatment of explants with water before culture initiation increased permeability of the epidermis layer and the tissue's water content and so enabled water, all solutes and plant 
growth regulators to transfer into the tissue more easily, providing all cells with a high regeneration capacity and consequently increasing explant's tissue culture response.

Shoots regenerated from water-treated and non-water-treated explants were rooted on MS medium containing $3 \mathrm{mg} \mathrm{l}^{-1}$ IBA for 3 weeks. The best results were obtained in the shoots regenerated from water-treated explants (Figure 10c). Sharp and dramatic differences, which were all statistically significant at the 0.01 level, were observed in all parameters between the shoots regenerated from water-treated and non water-treated explants (Table 3). Similar effects of water treatment were also noted in rooting stage. This means that shoots regenerated from water-treated explants were more capable of establishing new plantlets than the ones grown from non-water-treated explants.
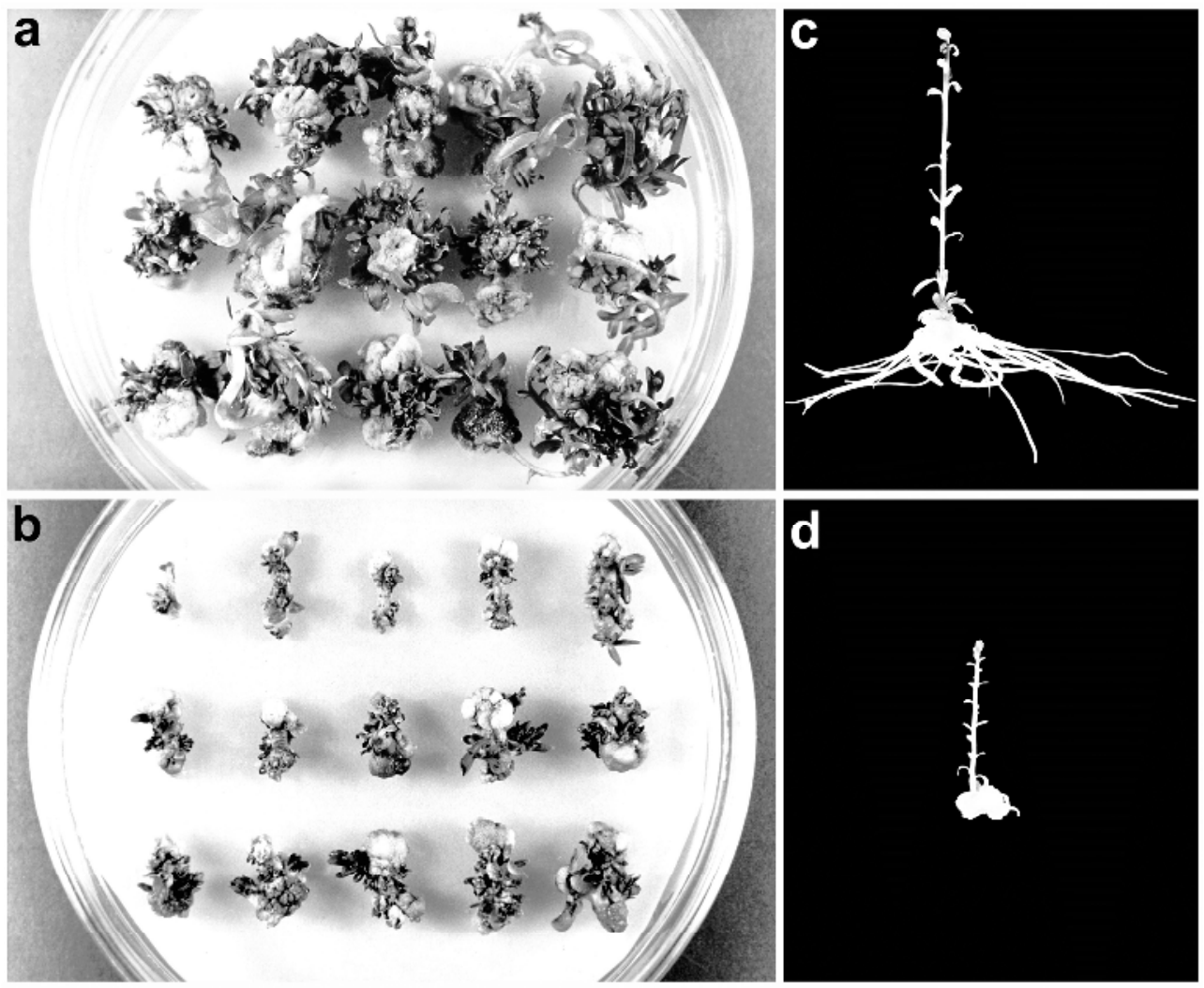

Figure 10. In vitro shoot regeneration from water-treated (a) and non-water-treated (b) hypocotyls of Linum usitatissimum cv. '1886 Sel.' from 6-week-old culture. In vitro rooting and development of shoots regenerated from water-treated (c) and non-water-treated (d) hypocotyls of Linum usitatissimum cv. '1886 Sel.' 3 weeks later. 


\begin{tabular}{|c|c|c|c|c|c|c|}
\hline \multirow[t]{2}{*}{ Cultivar } & \multicolumn{2}{|c|}{ Shoot length (cm) } & \multicolumn{2}{|c|}{ Number of roots } & \multicolumn{2}{|c|}{$\begin{array}{l}\text { Mean length of each root } \\
(\mathrm{cm})\end{array}$} \\
\hline & WT & NWT & WT & NWT & WT & NWT \\
\hline 'Madaras' & $3.02 \pm 0.225$ & $1.65 \pm 0.209$ & $10.20 \pm 1.519$ & $6.50 \pm 1.053$ & $1.58 \pm 0.156$ & $1.16 \pm 0.192$ \\
\hline '1886 Sel.' & $3.98 \pm 0.220$ & $1.28 \pm 0.185$ & $21.31 \pm 2.121$ & $7.19 \pm 1.342$ & $1.92 \pm 0.144$ & $0.82 \pm 0.076$ \\
\hline 'Clarck' & $4.81 \pm 0.396$ & $2.10 \pm 0.156$ & $29.00 \pm 2.887$ & $14.63 \pm 1.812$ & $2.33 \pm 0.223$ & $1.56 \pm 0.143$ \\
\hline
\end{tabular}

In all cases, the values for WT and NWT were significantly different at 0.01 level with the exception of mean length of each root of shoots of Madaras which is different at 0.05

Table 3. In vitro root development of shoots regenerated from water-treated (WT) and non-watertreated (NWT) hypocotyl explants on rooting medium enriched with $3 \mathrm{mg} \mathrm{l}^{-1} \mathrm{IBA} 3$ weeks after culture initiation

\subsection{Regulating osmotic pressure of explant}

In another study conducted by Yildiz et al. [77], pretreated and non-pretreated hypocotyl explants of three flax cultivars ('Omega', 'Fakel' and 'Ariane') were cultured for adventitious shoot regeneration. Two different pretreatment applications were compared to the conventional regeneration protocol with respect to hypocotyl fresh and dry weights, shoot regeneration percentage, shoot number per hypocotyl, shoot length and total chlorophyll content. In the $1^{\text {st }}$ and $2^{\text {nd }}$ pretreatment applications, hypocotyl explants were kept in sterile cabin under air flow for $30 \mathrm{~min}$. in order to make them dry as reported by Christmann et al. [78] to decrease the tissue water content and to gain explants the ability of uptaking increased amount of water, all solutes and plant growth regulators by using osmotic pressure in consequent applications. Then explants were treated with MS solution containing $1 \mathrm{mg} \mathrm{l}^{-1} \mathrm{BAP}$ and $0.02 \mathrm{mg} \mathrm{l}^{-1} \mathrm{NAA}$ for $15 \mathrm{~min}$. Finally all explants were cultured on MS medium without growth regulators in the $1^{\text {st }}$ pretreatment application and on MS medium enriched with $1 \mathrm{mg} \mathrm{l}^{-1} \mathrm{BAP}$ and $0.02 \mathrm{mg} \mathrm{l}^{-1} \mathrm{NAA}$ in the $2^{\text {nd }}$ pretreatment application. It was expected that by immersing explants into liquid regeneration medium after drying enabled all cells to absorb more growth regulators along with water in both pretreatment applications. However, only in $2^{\text {nd }}$ pretreatment application, explants were cultured on MS medium containing $1 \mathrm{mg} \mathrm{l}^{-1} \mathrm{BAP}$ and $0.02 \mathrm{mg} \mathrm{l}^{-1} \mathrm{NAA}$ which means that tissues maintained uptaking increased water and growth regulators from the regeneration medium which led to higher results in all parameters studied as reported by Yildiz and Ozgen [41]. Likewise, Okubo et al. [79] have reported that endogenous hormone levels of tissue affected regeneration capacity in vitro significantly. Fatima et al. [80] have also noted that internal factors such as chemicals and mineral nutrients affect in vitro plant growth. The required amount of exogenous plant growth regulators for cultured tissues depends on the endogenous levels plant tissues have [80]. It was first reported that keeping explants in sterile distilled water for $20 \mathrm{~min}$. before culture on MS medium enriched with $1 \mathrm{mg} \mathrm{l}^{-1}$ BAP and $0.02 \mathrm{mg} \mathrm{l}^{-1} \mathrm{NAA}$ increased the regeneration capacity of hypocotyls of flax tremendously by increasing permeability of the epidermis layer and tissue's water content and enabling water, all solutes and growth regulators to transfer into the tissue more easily [41]. 
According to the results, there were statistically significant differences among pretreated and non-pretreated hypocotyls in all cultivars (Table 4).

\begin{tabular}{|c|c|c|c|c|c|c|c|}
\hline \multirow[b]{2}{*}{ Cultivar } & \multirow{2}{*}{$\begin{array}{l}\text { Pre. } \\
\text { App. }\end{array}$} & \multicolumn{2}{|c|}{ Hypocotyl } & \multirow{2}{*}{$\begin{array}{c}\text { Shoot } \\
\text { regeneration } \\
(\%)^{*}\end{array}$} & \multirow{2}{*}{$\begin{array}{c}\text { Shoot } \\
\text { number per } \\
\text { hypocotyl }\end{array}$} & \multirow{2}{*}{$\begin{array}{l}\text { Shoot } \\
\text { length } \\
(\mathrm{cm})\end{array}$} & \multirow{2}{*}{$\begin{array}{c}\text { Total } \\
\text { chlorophyll } \\
\text { content ( } \mu \mathrm{g} / \mathrm{g} \\
\text { fresh tissue) }\end{array}$} \\
\hline & & $\begin{array}{c}\text { Fresh weight } \\
\text { (g) }\end{array}$ & Dry weight (g) & & & & \\
\hline \multirow{3}{*}{ 'Omega' } & 1 & $0.25^{* *} \pm 0.020 \mathrm{c}$ & $0.014 \pm 0.0019 b$ & $82.40 \pm 1.07 \mathrm{~b}$ & $6.76 \pm 0.46 b$ & $1.93 \pm 0.13 b$ & $217.1 \pm 10.40 \mathrm{c}$ \\
\hline & 2 & $0.48 \pm 0.023 a$ & $0.034 \pm 0.0023 a$ & $100.00 \pm 0.00 \mathrm{a}$ & $11.38 \pm 0.69 a$ & $2.82 \pm 0.14 \mathrm{a}$ & $380.6 \pm 26.91 \mathrm{a}$ \\
\hline & 3 & $0.37 \pm 0.017 \mathrm{~b}$ & $0.018 \pm 0.0017 \mathrm{~b}$ & $90.00 \pm 5.77 \mathrm{ab}$ & $7.99 \pm 0.74 b$ & $1.51 \pm 0.17 \mathrm{~b}$ & $286.2 \pm 10.45 b$ \\
\hline \multirow{3}{*}{ 'Fakel' } & 1 & $0.21 \pm 0.027 \mathrm{~b}$ & $0.016 \pm 0.0030 \mathrm{~b}$ & $72.00 \pm 7.53 b$ & $6.42 \pm 0.19 c$ & $1.05 \pm 0.11 \mathrm{~b}$ & $197.0 \pm 15.40 \mathrm{c}$ \\
\hline & 2 & $0.42 \pm 0.006 a$ & $0.032 \pm 0.0046 a$ & $100.00 \pm 0.00 \mathrm{a}$ & $8.89 \pm 0.37 a$ & $1.61 \pm 0.18 \mathrm{a}$ & $316.5 \pm 14.37 \mathrm{a}$ \\
\hline & 3 & $0.31 \pm 0.045 b$ & $0.024 \pm 0.0031 \mathrm{ab}$ & $80.60 \pm 7.45 \mathrm{a}$ & $7.49 \pm 0.10 \mathrm{~b}$ & $0.96 \pm 0.10 \mathrm{~b}$ & $252.1 \pm 9.89 b$ \\
\hline \multirow{3}{*}{ 'Ariane' } & 1 & $0.19 \pm 0.024 b$ & $0.014 \pm 0.0023 b$ & $46.23 \pm 6.20 \mathrm{c}$ & $4.26 \pm 0.18 b$ & $1.27 \pm 0.06 \mathrm{~b}$ & $192.0 \pm 11.25 c$ \\
\hline & 2 & $0.36 \pm 0.055 \mathrm{a}$ & $0.030 \pm 0.0012 \mathrm{a}$ & $100.00 \pm 0.00 a$ & $6.64 \pm 0.25 a$ & $2.00 \pm 0.13 \mathrm{a}$ & $346.0 \pm 18.62 \mathrm{a}$ \\
\hline & 3 & $0.26 \pm 0.026 \mathrm{ab}$ & $0.019 \pm 0.0018 b$ & $65.35 \pm 3.76 b$ & $4.59 \pm 0.07 \mathrm{~b}$ & $1.06 \pm 0.09 b$ & $268.2 \pm 24.10 \mathrm{~b}$ \\
\hline
\end{tabular}

Pretreatment applications;

1. Hypocotyls were waited for $30 \mathrm{~min}$. in sterile cabin under air flow and for $15 \mathrm{~min}$. in solution containing $1 \mathrm{mg} \mathrm{l}^{-1}$

$\mathrm{BAP}+0.02 \mathrm{mg} \mathrm{l}^{-1} \mathrm{NAA}$ and finally cultured on MS0 medium

2. Hypocotyls were waited for $30 \mathrm{~min}$. in sterile cabin under air flow and for $15 \mathrm{~min}$. in solution containing $1 \mathrm{mg} \mathrm{l}^{-1}$

$\mathrm{BAP}+0.02 \mathrm{mg} \mathrm{l}^{-1} \mathrm{NAA}$ and finally cultured on MS medium containing $1 \mathrm{mg} \mathrm{l}^{-1} \mathrm{BAP}+0.02 \mathrm{mg} \mathrm{l}^{-1} \mathrm{NAA}$

3. Hypocotyls were cultured directly on MS medium containing $1 \mathrm{mg} \mathrm{l}^{-1} \mathrm{BAP}+0.02 \mathrm{mg} \mathrm{l}^{-1} \mathrm{NAA}$ (non-pretreated)

"The values represent mean \pm standard error of the mean

${ }^{* *}$ Values within a column for each cultivar followed by different letters are significantly different at the 0.01 level.

Table 4. Tissue culture response from pretreated and non-pretreated hypocotyls of three flax cultivars 6 weeks after culture initiation

The highest results in both fresh and dry weights of hypocotyls of all cultivars were obtained from $2^{\text {nd }}$ pretreatment application. Scores of fresh and dry weights were followed by nonpretreated hypocotyls. The lowest results were recorded from $1^{\text {st }}$ pretreatment application in all cultivars studied (Table 4). From the results, it could be concluded that increases in the fresh and dry weights were chiefly due to an increase in the absorption of water and growth regulators from the medium where explants were first pretreated and then cultured. When the results of $2^{\text {nd }}$ pretreatment application were examined, it could be easily seen that culturing explants on MS medium containing $1 \mathrm{mg} \mathrm{l}^{-1} \mathrm{BAP}$ and $0.02 \mathrm{mg} \mathrm{l}^{-1} \mathrm{NAA}$ after treating them with liquid MS medium supplemented with $1 \mathrm{mg} \mathrm{l}^{-1} \mathrm{BAP}$ and $0.02 \mathrm{mg} \mathrm{l}^{-1} \mathrm{NAA}$ clearly enriched the tissue's growth regulators level which caused to higher fresh and dry weights.

The results related to shoot regeneration percentage indicated that the lowest results were obtained from the $1^{\text {st }}$ pretreatment application in all cultivars. Hypocotyl explants formed roots and fewer callus in the $1^{\text {st }}$ pretreatment application than the others. All explants regenerated successfully in the $2^{\text {nd }}$ pretreatment application and consequently shoot regeneration percentage was recorded as $100 \%$ in all cultivars studied (Table 4, Figure 11).

The highest results in shoot number per hypocotyl and shoot length were obtained from $2^{\text {nd }}$ pretreatment application in all cultivars studied. The highest shoot number per hypocotyl was recorded as 11.38 in 'Omega', 8.89 in 'Fakel' and 6.64 in 'Ariane'. The highest scores related to 

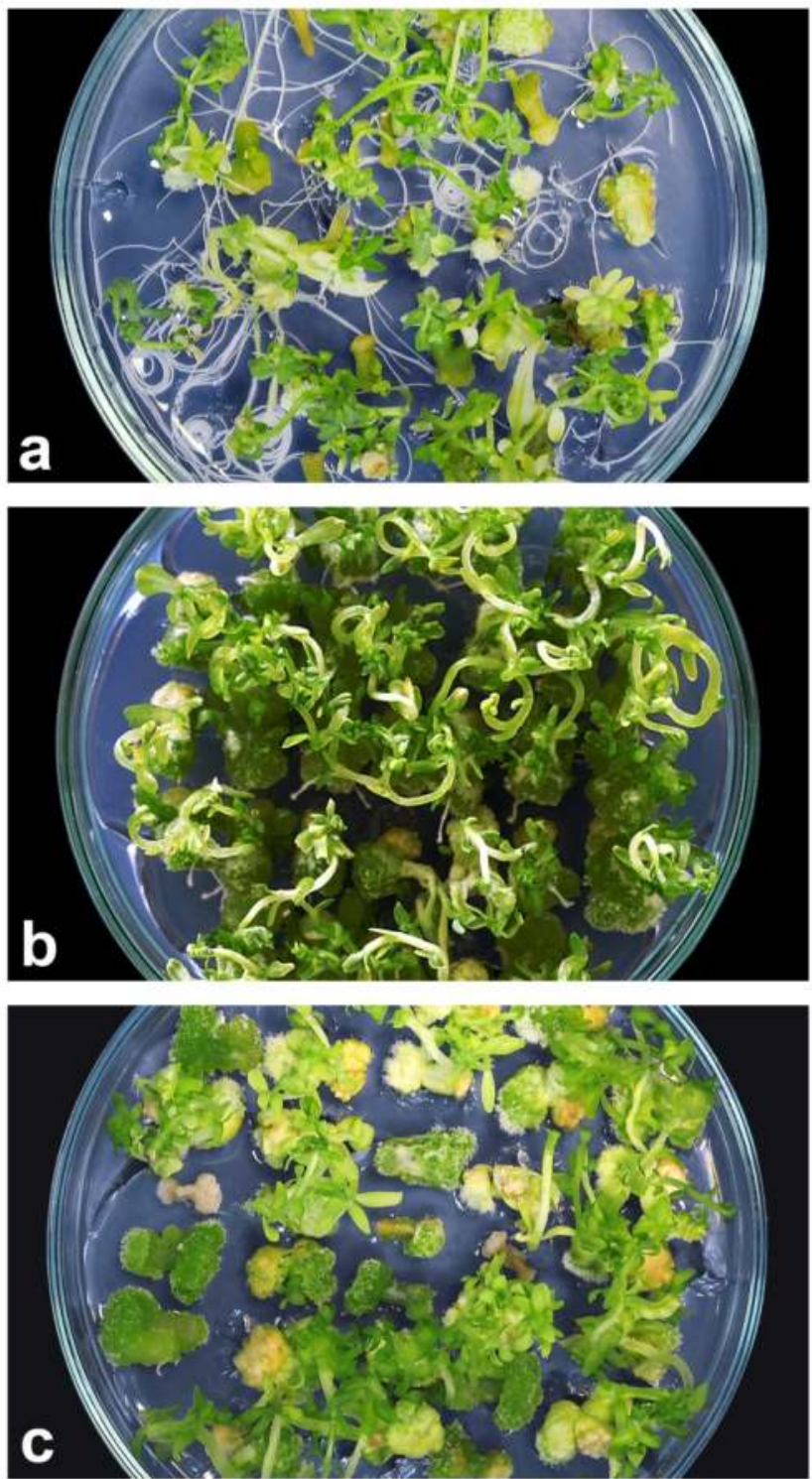

Figure 11. In vitro shoot regeneration from pretreated and non-pretreated hypocotyls of flax (Linum usitatissimum) cv. 'Omega'. (a) $1^{\text {st }}$ pretreatment application: Hypocotyls were waited for $30 \mathrm{~min}$. in sterile cabin under air flow and treated with solution containing $1 \mathrm{mg} / \mathrm{l} \mathrm{BAP}$ and $0.02 \mathrm{mg} / \mathrm{l} \mathrm{NAA}$ for $15 \mathrm{~min}$. and finally cultured on MS0 medium, (b) 2nd pretreatment application: Hypocotyls were waited for 30 $\mathrm{min}$. in sterile cabin under air flow and treated with solution containing $1 \mathrm{mg} / \mathrm{l} \mathrm{BAP}$ and $0.02 \mathrm{mg} / \mathrm{l} \mathrm{NAA}$ for $15 \mathrm{~min}$. and finally cultured on MS medium containing $1 \mathrm{mg} / \mathrm{l} \mathrm{BAP}+0.02 \mathrm{mg} / \mathrm{l} \mathrm{NAA}$, (c) Nonpretreatment application: Hypocotyls were directly cultured on MS medium containing $1 \mathrm{mg} / \mathrm{l}$ BAP+0.02 mg/l NAA 
shoot length were 2.82, 1.61 and $2.00 \mathrm{~cm}$ in 'Omega', 'Fakel' and 'Ariane', respectively. Shoot regeneration capacity of hypocotyls increased significantly in $2^{\text {nd }}$ pretreatment application. The best results in total chlorophyll content were obtained from $2^{\text {nd }}$ pretreatment application in all cultivars. The highest scores of total chlorophyll content were recorded as $380.6 \mu \mathrm{g} / \mathrm{g}$ fresh tissue in 'Omega', $316.5 \mu \mathrm{g} / \mathrm{g}$ fresh tissue in 'Fakel' and 346.0 in 'Ariane' (Table 4). The explants to which $2^{\text {nd }}$ pretreatment application was carried out were more vital and well-grown and more capable of regeneration (Figure 11). Emerson [81] reported that there is a close relationship between photosynthesis and chlorophyll content. Chlorophyll content of leaf is considered as a sign of photosynthetic capacity of tissues [81-84] which plays a critical role in plant growth and development [85] and its amount changes under stress conditions [86-88]. Gireesh [89] has reported that chlorophyll can be used to measure growth.

From the results, it could be concluded that the lower levels of all parameters recorded in the $1^{\text {st }}$ and $3^{\text {rd }}$ pretreatment applications were directly due to a decreased uptake of water and growth regulators from the medium. Tissue culture response has been affected significantly by tissue water content [41]. Treatment of explants with liquid MS medium containing $1 \mathrm{mg} \mathrm{l}^{-1}$ BAP and $0.02 \mathrm{mg} \mathrm{l}^{-1} \mathrm{NAA}$ for a while before culture initiation enabled water, all solutes and plant growth regulators to transfer into the tissue much more, providing all cells with a high regeneration capacity and consequently increasing explant's tissue culture response.

\section{Conclusion}

Plant tissue culture techniques help us to propagate plants vegetatively in a large amount starting from small parts of a tissue and by using the potential of known as totipotency, to form a whole, fertile plant. Plant tissue culture studies are performed on an artificial growth medium under sterile conditions. Explants regenerate shoots and roots, and consequently whole fertile plants under certain cultural conditions. Tissue culture studies aim to obtain high-frequency shoot regeneration, which is also a prerequisite for an efficient transformation system and a clonal propagation of plants. The introduction of foreign genes coding agronomically important traits into plant cells has no meaning unless transgenic plants are regenerated from the genetically modified cell(s). Therefore, using tissues having high regeneration capacity is extremely important. Regeneration capacity of cells or tissues to be used in transformation studies, affects the success of genetic transformation significantly. The types and concentrations of plant growth regulators in plant cell culture significantly affect growth and morphogenesis. In order to obtain high frequency adventitious shoot regeneration for related genotype, correct concentrations and combinations of auxins and cytokinins should be determined. However, determining the explant type, and correct concentrations and combinations of growth regulators is not enough for high frequency shoot regeneration. Since every cell has an ability of forming a whole fertile plant under in vitro conditions, shoot regeneration frequency can always be higher than we obtain in theory. Many factors affecting regeneration capacity of explant are not found out yet. For instance, a recently reported technique utilizing competition among explants is very effective to increase shoot regeneration capacity. Thus, unknown factors affecting regeneration capacity of explants should be determined in order to increase the success of tissue culture studies. 


\section{Author details}

Mustafa Yildiz*

Department of Field Crops, Faculty of Agriculture, University of Ankara, Diskapi, Ankara, Turkey

\section{References}

[1] Huetteman CA, Preece JE. Thidiazuron: a potent cytokinin for woody plant tissue culture. Plant Cell Tissue Organ Culture 1993; 33: 105-119.

[2] Mantell SH, Haque SQ, Whitehall AP. Clonal multiplication of Dioscorea alata L. and Dioscoren rotiindata Poir. yams by tissue culture. Journal of Horticultural Science 1978; 53(2): 95-98.

[3] Pierik RLM. In vitro Culture of Higher Plants. Martinus Nijhoff Publishers, Dordrect; 1987.

[4] Tisserat B. Embryogenesis, Organogenesis and Plant Regeneration. In: Dixon RA. (ed). Plant Cell culture: A Practical Approach. IRL Press, Oxford, Washington DC; 1985, p79105.

[5] Skoog F, Tsui C. Chemical control of growth and bud formation in tobacco stem segments and callus cultured in vitro. American Journal of Botany 1948; 35: 782-787.

[6] Earle ED, Torrey JG (1965) Morphogenesis in cell colonies grown from Convolvulus cell suspensions plated on synthetic media. American Journal of Botany, 52: 891-899.

[7] Gürel E. Transferring an antimicrobial gene into Agrobacterium and tobacco. May 20-22, 1998, 2nd International Kizilirmak Fen Bilimleri Congress, Kırıkkale University, Kirikkale, Turkey.

[8] Kaul K, Sabharwal PS. Morphogenetic studies on Haworthia: Establishment of tissue culture and control of differentiation. American Journal of Botany 1972; 59: 377-385.

[9] Gürel S, Gürel E, Kaya Z. Ovule culture in sugar beet (Beta vulgaris L.) breeding lines. May 20-22, 1998, 2nd International Kizılırmak Fen Bilimleri Congress, Kırıkkale University, Kirikkale, Turkey.

[10] Gürel E, Kazan K. Development of an efficient plant regeneration system in sunflower (Helianthus annuus L.) Turkish Journal of Botany 1998; 22: 381-387.

[11] Yildiz M. 2000. Adventitious shoot regeneration and Agrobacterium tumefaciensmediated gene transfer in flax (Linum usitatissimum L.). PhD thesis. University of Ankara, Graduate School of Natural and Applied Sciences, Department of Field Crops. Ankara; 2000.

[12] Tran Thanh Van K. Control of morphogenesis in in vitro cultures. Annual Review of Plant Physiology 1998; 32: 291-311.

[13] Sommer HE, Brown CK, Kormanik PP. Differentiation of plantlets in longleaf pine (Pinus palustris Mill.) tissue cultured in vitro. Botanical Gazette 1975; 136: 196-200.

[14] Vasil IK, Vasil V. Regeneration in Cereal and Other Grass Species. In: Vasil IK (ed.) Cell Culture and Somatic Cell Genetics of Plants. Academic Pres, New York; 1986. P121-150.

\footnotetext{
${ }^{*}$ Corresponding Author
} 
[15] Tetu T, Sangwan RS, Sangwan-Norreel BS. Hormonal control of organogenesis and somatic embryogenesis in Beta vulgaris callus. Journal of Experimental Botany 1987; 38: 506-517.

[16] Krens FA, Jamar D. The role of explant source and culture conditions on callus induction and shoot regeneration in sugarbeet (Beta vulgaris L.). Journal of Plant Physiology 1989; 134: 651-655.

[17] Budzianowska A. In vitro cultures of tobacco and their impact on development of plant biotechnology. Przeglad Lekarski 2009; 66(10): 890-893.

[18] Emeklier Y, Ozcan S, Avcı Birsin M, Mirici S, Uranbey S. Studies on in vitro somatic embryogenesis in maize. Ankara University, Research Fund Project, Ankara, Turkey; 1999.

[19] Mantell SH, Matthews JA, McKee RA. Principles of plant biotechnology. An introduction to genetic engineering in plants. Blackwell Scientific Publications, Oxford; 1985.

[20] Robb Sheila M. The Culture of Excised Tissue 3Lilium speciosum Thun. Journal of Experimental Botany, 1957, 8(3): 348-352.

[21] Pierik RLM. Meded. Landbouwhogeschool Wageningen 1967; 67(6): 1-71.

[22] Konar RN, Nataraja K. Morphogenesis of isolated floral buds of Ranunculus sceleratus L. in vitro. Acta Botanica Neerlandica 1969; 18: 680-699.

[23] Wright NA, Alderson PG. The growth of tulip tissues in vitro. Acta Horticulturae 1980; 109:263-270.

[24] Gürel E, Türker AU (2001) Organogenesis. In: Babaoğlu M, Gürel E, Özcan S (eds.) Plant Biotechnology, Tissue Culture and Applications. Selcuk University Publications, Konya, Turkey; 2001. P36-70.

[25] Yildiz M, Ozcan S, Er C. The effect of different explant sources on adventitious shoot regeneration in flax (Linum usitatissimum L.). Turkish Journal of Biology 2002; 26: 37-40.

[26] Yıldız M, Saglik Ç, Telci C, Erkilic EG. The effect of in vitro competition on shoot regeneration from hypocotyl explants of Linum usitatissimum. Turkish Journal of Botany 2011; 35: 211-218.

[27] Yıldız M, Ulukan H, Özbay A. The effect of different growth medium, gelling agents and explant age on shoot regeneration from hypocotyl explants in flax (Linum usitatissimum L.). XIIIrd Biotechnology Congress, Canakkale, Turkey; 2003.

[28] Evers PW. Growth and morphogenesis of shoot initials of Douglas fir, Pseudotsuga mensiesii (Mirb.) Franco, in vitro. Diss. Agric. Univ. Wageningen, the Netherlands. Article 1-6; 1984

[29] Wilson JB. Shoot competition and root competition. Journal of Applied Ecology 1998; 25: 279-296.

[30] McPhee CS, Aarssen LW. The seperation of above- and below-ground competion in plants. A review and critique of methodology. Plant Ecology 2001; 152: 119-136.

[31] [31] De Klerk GJ. Stress in plants cultured in vitro. Propagation of Ornamental Plants 2007; 7(3): 129-137.

[32] Yildiz M. Evaluation of the effect of in vitro stress and competition on tissue culture response of flax. Biologia Plantarum 2011; 55(3): 541-544. 
[33] Stoffella PJ, Bryan HH. Plant population influences growth and yields of bell pepper. Journal of the American Society for Horticultural Science 1988; 113: 835-839.

[34] Decoteau DR, Grahan HAH. Plant spatial arrangement affects growth, yield and pod distribution of cayenne peppers. HortScience 1994; 29: 149-151.

[35] Jolliffe PA, Gaye MM. Dynamics of growth and yield component responses of bell peppers (Capsicum annuum L.) to row covers and population density. Scientia Horticulturae 1995; 62: 153-164.

[36] Morgade L, Willey R. Effect of plant population and nitrogen fertilizer on yield and efficiency of maize/bean intercropping. Pesquisa Agropecuária Brasileira 2003; 38: 12571264.

[37] Abubaker S. Effect of plant density on flowering date, yield and quality attribute of bush beans (Phaseolus vulgaris L.) under center pivot irrigation system. American Journal of Agricultural and Biological Sciences 2008; 3: 666-668.

[38] Asghari MT, Daneshian J, Farahani AA. Effects of drought stress and planting density on quantity and morphological characteristics of chicory (Cichorium intybus L.). Asian Journal of Agricultural Sciences 2009; 1: 12-14.

[39] Gersani M, Brown JS, O'Brien E, Mania GM, Abramsky Z. Tragedy of the commons as a result of root competition. Journal of Ecology 2001; 89: 660-669.

[40] Maina GG, Brown JS, Gersani M. Intra-plant versus inter-plant root competiton in beans: avoidance, resource matching or tragedy of the commons. Plant Ecology 2002; 160: 235247.

[41] Yildiz M, Ozgen M. The effect of a submersion pretreatment on in vitro explant growth and shoot regeneration from hypocotyls of flax (Linum usitatissimum). Plant Cell Tissue and Organ Culture 2004; 77: 111-115.

[42] Dale JE. The control of leaf expansion. Annual Review of Plant Physiology 1988; 39: 267295.

[43] Sunderland N. Cell division and expansion in the growth of the leaf. Journal of Experimental Botany 1960; 11: 68-80.

[44] Ozcan S, Yildiz M, Sancak C, Ozgen M. Adventitious shoot regeneration in sainfoin (Onobrychis viciifolia Scop.). Turkish Journal of Botany 1996; 20: 497-501.

[45] Yildiz M, Er C. The effect of sodium hypochlorite solutions on in vitro seedling growth and shoot regeneration of flax (Linum usitatissimum). Naturwissenschaften 2002; 89, 259261.

[46] Allan A. (1991). Plant Cell Culture. In: Stafford A, Warren G. (eds.) Plant Cell and Culture. Open University Press, Milton Keynes; 1991. p1-24.

[47] Dixon RA, Gonzales RA. Plant Cell and Tissue Culture: A Practical Approach, 2nd ed. Oxford University Press, Oxford; 1994.

[48] Yildiz M, Avci M, Ozgen M. Studies on sterilization and medium preparation techniques in sugarbeet (Beta vulgaris L.) regeneration. In: Ulrich P. (ed.) TurkishGerman Agricultural Research Symposium V, Akdeniz University, Antalya, Turkey; 1997.

[49] Dunn CG. Food Preservatives. In: Lawrence CA, Block SS. (eds.) Disinfection, Sterilization, and Preservation. Lea and Febiger; 1968. p632-651. 
[50] Mercer WA, Somers II. Chlorine in food plant sanitation. Advences in Food Research 1957; 7: 129-169.

[51] Smith CR. Mycobactericidal Agents. In: Lawrence CA, Block SS. (eds.) Disinfection, Sterilization, and Preservation. Lea and Febiger; 1968. p504-514.

[52] Spaulding EH. Chemical Disinfection of Medical and Surgical Materials. In: Lawrence CA, Block SS. (eds.) Disinfection, Sterilization, and Preservation. Lea and Febiger; 1968. p517-531.

[53] Bietz JA, Sandford PA Reaction of sodium hypochlorite with amines and amides: Automation of the method. Analytical Biochemistry 1971; 44: 122-133.

[54] Kantouch A, Ardel-Fattah SH. Action of sodium hypochlorite on a-amino acids. Chemicke Zvesti 1971; 25: 222-230.

[55] Hayatsu H, Pan S, Ukita T. Reaction of sodium hypochlorite with nucleic acids and their constituents. Chemical and Pharmaceutical Bulletin 1971; 19: 2189-2192.

[56] Sandford PA, Nafziger AJ, Jeanes A. Reaction of sodium hypochlorite with amines and amides: A new method for quantitating amino sugars in manomeric form. Analytical Biochemistry 1971a; 42: 422-436.

[57] Sandford PA, Nafziger AJ, Jeanes A. Reactions of sodium hypochlorite with amines and amides: A new method for quantitating polysaccharides containing hexosamines. Analytical Biochemistry 1971b; 44: 111-121.

[58] Hsiao AI, Hans JA. Application of sodium hypochlorite seed viability test to wild oat populations with different dormancy characteristics. Canadian Journal of Plant Science $1981 ; 61,115-122$.

[59] Hsiao AI, Quick AW. Action of sodium hypochlorite and hydrogene peroxide on seed dormancy and germination of wild oats, Avena fatua L. Weed Research 1984; 24, 411419.

[60] Telci C, Yildiz M, Pelit S, Onol B, Erkilic EG. Kendir, H. The effect of surfacedisinfection process on dormancy-breaking, seed germination, and seedling growth of Lathyrus chrysanthus Boiss. under in vitro conditions. Propagation of Ornamental Plants 2011; 11: 10-16.

[61] Racoppi F. Domestic Bleaches Containing Sodium Hypochlorite, Procter and Gamble, Italia SPA, Product Development Department, Rome; 1990.

[62] Schull W. Temperature and rate of moisture intake in seeds. Botanical Gazette 1920; 69: 361-390.

[63] Murashige T, Skoog F. A revised medium for rapid growth and bioassays with tobacco tissue cultures. Physiologia Plantarum 1962; 15: 431-497.

[64] Gamborg OL, Miller RA, Ojima K. Nutrient requirements of suspension cultures of soybean root cells. Experimental Cell Research 1968; 50: 151-158.

[65] Chu CC. The N6 medium and its applications to anther culture of cereal crops. In: Proceedings of Symposium on Plant Tissue Culture. Science Press, Beijing; 1978.

[66] Nitsch JP, Nitsch C. Haploid plants from pollen grains. Science 1969; 163: 85-87.

[67] Driver JA, Kuniyuki AH. In vitro propagation of paradox walnut rootstocks. Hortscience 1984; 19: 507-509. 
[68] Lloyd G, McCown B. Commercially feasible micropropagation of mountain laurel, Kalmia latifolia, by use of shoot tip culture. International Plant Propagator's Society Combined Proceedings; 1980.

[69] Gamborg OL, Phillips GC. Plant Cell Tissue Organ Culture. Narosa Publishing House, New Delhi; 1995.

[70] Fisher RA. Influence of Water Stress on Crop Yield in Semi Arid Regions. In: Turner NC, Kramer P (eds.) Adaptation of Plants to Water and High Temperature Stress. Willey and Son, New York; 1980. P323-340.

[71] Kriedeman PE, Barrs HD. Citrus Orchards. In: Koziowski TT (ed.) Water Deficit and Plant Growth. Academic Press, New York; 1981. p325-417.

[72] Hadas A. Water uptake and germination of Leguminous seeds under changing external water potential in osmotic solutions. Journal of Experimental Botany 1976; 27(3): 480489.

[73] Hsiao TC. Plant responses to water stress. Annual Review of Plant Physiology 1973; 24: 219-270.

[74] Van Volkenburg E, Boyer JS. Inhibitory effects of water deficit on maize leaf elongation. Plant Physiology 1985; 77: 190-194.

[75] Kahn A. An analysis 'dark-osmotic inhibition' of germination of lettuce seeds. Plant Physiology 1960; 35: 1-7

[76] Morgan PW. Effects of Abiotic Stresses on Plant Hormone Systems. In: Koziowski TT (ed.) Stress Responses in Plants: Adaptation and Acclimation Mechanism. New York: Wiley-Liss; 1990. p113-146.

[77] Yildiz M, Ozcan S, Telci C, Day S, Özat H. The effect of drying and submersion pretreatment on adventitious shoot Regeneration from hypocotyl explants of flax (Linum usitatissimum L.). Turkish Journal of Botany 2010; 34: 323-328

[78] Christmann A, Hoffman T, Teplova I, Grill E, Muller A. Generation of active pools for abscisic acid revealed by in vivo imaging of water-stressed Arabidopsis. Plant Physiology 2005; 137: 209-219.

[79] Okubo H, Wada K, Uemoto S. In vitro morphogenetic response and distribution of endogenous plant hormones in hypocotyl segments of snapdragon (Antirrhinum majus L.). Plant Cell Reports 1991; 10: 501-504.

[80] Fatima Z, Mujib A, Fatima S, Arshi A, Umar S. Callus induction, biomass growth, and plant regeneration in Digitalis lanata Ehrh.: influence of plant growth regulators and carbonhydrates. Turkish Journal of Botany 2009; 33: 393-405.

[81] Emerson R. Chlorophyll content and the rate of photosynthesis. Proceedings of the National Academy of Sciences of the United States of America 1929; 15(3): 281-284.

[82] Pal RN, Laloraya MM. Effect of calcium levels on chlorophyll synthesis in peanut and linseed plants. Biochemie und Physiologie der Pflanezen 1972; 163: 443-449.

[83] Wright GC, Nageswara RRC, Farquhar GD. Water use efficiency and carbon isotope discrimination in peanut under water deficit conditions. Crop Science 1994; 34: 92-97.

[84] Nageswara RRC, Talwar HS, Wright GC. Rapid assessment of specific leaf area and leaf nitrogen in peanut (Arachis hypogaea L.) using chlorophyll meter. Journal of Agronomy and Crop Science 2001; 189: 175-182. 
[85] Yang X, Wang X, Wei M. Response of photosynthesis in the leaves of cucumber seedlings to light intensity and $\mathrm{CO}_{2}$ concentration under nitrate stress. Turkish Journal of Botany 2010; 34: 303-310.

[86] Rensburg LV, Kruger GHJ. Evaluation of components of oxidative stres metabolism for use in selection of drought tolerant cultivars of Nicotiana tabacum L. Journal of Plant Physiology 1994; 143: 730-737.

[87] Kyparissis A, Petropoulou Y, Manetas Y. Summer survival of leaves in a soft-leaved shrub (Phlomis fruticosa L., Labiatae) under Mediterranean field conditions: Avoidance of photoinhibitory damage through decreased chlorophyll contents. Journal of Experimental Botany 1995; 46: 1825-1831.

[88] Jagtap V, Bhargava S, Sterb P, Feierabend J. Comparative effect of water, heat and light stresses on photosynthetic reactions in Sorghum bicolor (L.) Moench. Journal of Experimental Botany 1998; 49: 1715-1721.

[89] Gireesh R. Proximate composition, chlorophyll a, and carotenoid content in Dunaliella salina (Dunal) Teod (Chlorophycea: Dunaliellaceae) cultured with cost-effective seaweed liquid fertilizer medium. Turkish Journal of Botany 2009; 33: 21-26. 